\title{
Designing Social Question-and-Answering Interaction Using Goal-Directed Design Method
}

\author{
Muhammad Banirahma Syahroni ${ }^{\#}$, Harry Budi Santoso ${ }^{\#}$ \\ ${ }^{\#}$ Faculty of Computer Science, Universitas Indonesia, Kampus Baru UI Depok, Depok - Jawa Barat, 16424, Indonesia \\ E-mail:email@bani.us, harrybs@cs.ui.ac.id
}

\begin{abstract}
A social question-and-answering (social Q\&A) site is an online community where users can ask and answer questions to share their knowledge and all data are publicly accessible. The platform has caught its users' attention and given them a new way in getting information from other users. However, the growth of social Q\&A sites is still followed by some problems faced by its users. This study aims to develop an interaction design of social Q\&A using goal-directed design (GDD) method. The process accomplished in the development includes four phases: research, modelling, requirement definition, and framework definition. The series of phases resulted in personas, scenarios, requirements, and wireframes of the product. Social Q\&A product developed in the study is one that is specialized for asking and sharing information about studying abroad.
\end{abstract}

Keywords - interaction design; social Q\&A; goal-directed design.

\section{INTRODUCTION}

Social question-and-answering (social Q\&A) sites, also commonly known as community question-answering (CQA) sites, are online communities where users can ask questions and share their answers, and all data are public and searchable [1]. In the last few years, the platform has been attracting many users and providing a new way for them to get information from other users. They commonly search for specific and detail information, which usually requires a response from people who have a particular experience [2]. Some well-known social Q\&A sites are Yahoo Answers and Quora. In addition, there are also social Q\&A sites that focus on a specific topic, such as Stack Overflow that facilitates question-and-answering about programming.

Even though social Q\&A offers many benefits, its growth is still accompanied by some problems faced by users. One opinion about the cause of this is due to the increasing number of low-value questions, making it difficult for users to find the useful or entertaining content [2]. A preliminary survey we did to 291 users of Yahoo Answers (45.7\%), Stack Overflow (19.5\%), Quora (16.8\%), Brainly (16.1\%), and Stack Exchange (1.3\%) shows that there are problems their users are still facing in using the sites. The overall result shows that $23 \%$ of the respondents admitted not to recommend the sites to others, $32.3 \%$ gave a score of 7 or less for sites performance, and $21.9 \%$ gave a score of 7 or less for sites ease of use.

One factor that affects how a product tackles user problem is the design method used in developing the product. This study was conducted to develop the modeling, requirements, and interaction design of a social Q\&A site by utilizing a goal-directed design (GDD) method. GDD is a product and service design approach developed in Cooper, a design consulting from California, United States. The rationale of the method is that the best way to design a successful product is to focus on the goals of the user [3].

The case used in this study is a social Q\&A site for asking and sharing information about studying abroad. The reason we chose this topic is that the number of keyword searches about studying abroad conducted by Indonesian people through Google is quite high and continues to rise. This indicates public awareness increase about quality of higher education in Indonesia. Along with the increasing number of Indonesian people who are interested in studying abroad, the needs for information about it will undoubtedly increase. Throughout this study, we expected to create an interaction design of a social Q\&A site that allows Indonesian people to obtain and provide valuable information about studying abroad.

The popularity of social Q\&A makes this platform develops its design principles and patterns. Ortbach et al. [4] identified 27 design principles in social Q\&A, such as following a question, scoring a question, and direct communication between two users. Question routing or approach in displaying questions to users can be divided into two categories according to [5]: feature-based approach, and social network-based approach. In addition, there are two reputation mechanisms in social Q\&A: open, as Yahoo 
Answers uses, and closed, as Quora uses with its PeopleRank algorithm [6].

Several studies about social Q\&A from the user's perspective have also been conducted. Most users in social Q\&A come from search engine result pages [7], and their motivation in contributing knowledge through the platform are self-presentation, recognition of other members, and social learning opportunities [8]. Gazan classified users who ask questions in Answerbag, a social Q\&A, into two categories: seeker and sloth [9], and classified users who answer questions into two categories: specialist and synthesis [10]. In assessing the answers, users consider 24 criteria, such as approval, the feasibility of solution, and effectiveness [11].

\section{MATERIAL AND METHOD}

Online question-answering (Q\&A) services allow people to post a question online and receive responses from participants within an online Q\&A community. These services provide a way to ask a question directly, so the participants could answer based on the asker's information and need rather than a summary list of links displayed on a search engine results page (SERP) [12].

Research in online Q\&A area can be characterized in three ways; there are user or content-based, based on the type of online Q\&A site, or focuses on askers or answerers. [13]-[15]. Particularly, researchers in this field have been focused on these aspects.

From those aspects, what is highlighted in this paper is Q\&A that focuses on askers or answerers. Askers or answerers have their motivation in asking or answering through Q\&A platform. Pi et al. identified that the people behavior in sharing knowledge on social media drive people to share it in Facebook groups too. User's behavior on sharing knowledge has positively affected by how much reputation that she/he will get some pride because they can help people and subjective norm from another user that expect certain people to share their knowledge [16]. Others than motivation, an online social network connects friends with the real-life relationship and online friendship, which shares similarity to the real-life social networks. It usually tends to gather people with the same interest [17]. This social question answering sites use a collaborative paradigm to satisfy complex information needs. [18]

In line with designing the online (Q\&A) services, three design methods was often used including user-centered design (UCD), activity-centered design (ACD), and goaldirected design (GDD). In ACD, the design process does not focus on tasks, activities users have to do with the system but what tasks or activities should be supported by the system [19]. UCD and GDD are two methods that focus on the users, but GDD has more specific process compared to UCD. The process of GDD is divided into six phases: research, modeling, requirement definition, framework definition, design refinement, and design support [3].

Cooper et al. [3] wrote that in the process of GDD, users are modeled into a persona. Persona provides a way of thinking and communicating about how a group of users behaves, how they think, and what they want to accomplish and why. Each persona has goals, the drivers that motivate persona to behave as they do. Goals provide answers to why and how a persona use the product. For each persona, there will be scenarios that describe an ideal experience of product use from a persona perspective, focusing on how users think and act. Cooper et al. [3] defined design requirements as information and capabilities personas require achieving their goals. They are identified to avoid designers directly jump into the solution. Requirements are identified based on scenarios constructed before. In addition, Cooper et al. [3] also defined design framework as the overall structure of user experience. There are four types of design framework: interaction framework, visual design framework, industrial design framework, and service design framework.

In this study, the last two phases of GDD, design refinement and design support, were not conducted because the focus of it is on the interaction design. The phases conducted in the study followed the detailed steps [3].

Research is the data collection phase to understand the problem. This phase was done by conducting a literature review and potential user interview. The literature review was conducted in order to gain more information about how existing social Q\&As, such as Yahoo! Answer, Quora, and Stack Overflow, work and how their users use it. Academic papers we reviewed such as about user categorization, user motivation, and scoring mechanism. Potential user interview was conducted to understand behavior, attitude, and aptitude of potential users. The interview process followed the approach of an in-depth interview.

Modeling is the data analysis phase to explore behavior patterns and combine them into the user model. Modeling was started with the analysis of data obtained from potential user interview and ended with output a set of persona. There are eight steps in constructing persona as written in [3]: grouping interview participants based on their role; identify behavioral variables; map interview participants to behavioral variables; identify significant behavior patterns; synthesize characteristics and define goals; check completeness and redundancy, and designate persona types.

Requirement definition is the analysis phase of data obtained from the two previous phases to determine product functionality and design. In this phase, user scenarios that describe how a persona uses the product were developed. There are five steps in the phase with the possibility of iterations in the third to the fifth stage as written in [3]: define the problem and vision statements; explore and brainstorm; identify persona expectations; construct context scenarios, and identify design requirements.

Framework definition is the necessary framework development phase of product shape and behavior. The development used the personas and scenarios that have been created before, as well as utilized the design patterns and principles. Due to the study focus, the framework developed in the phase is the interaction framework only. The interaction framework definition can be done through six steps with the possibility of iteration in the third to the fifth stage as written in [3]: define form factor, posture, and input methods; define functional and data elements; define functional groups and hierarchy; sketch interaction framework; construct key path scenarios; and check designs check validation scenarios. 


\section{RESULTS AND DISCUSSION}

Implementation of GDD process was started with a research phase, followed by modeling, requirement definition, and ended with framework definition. The process chart can be seen on Fig. 1.

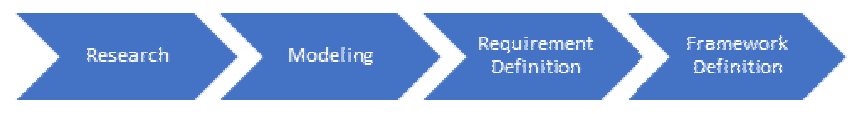

Fig. 1 GDD process followed through

\section{A. Research}

The research method used in this phase is an interview with potential users as participants. In the beginning, we identified two leading roles in social Q\&A for asking and sharing information about study abroad: Indonesian people who want to continue his study abroad as information seeker and Indonesian people who are studying abroad as an information provider. The two roles were then defined as the persona hypothesis and used as references in defining interview participants. For each role in persona hypothesis, eight participants were asked for an interview. There are 16 participants interviewed: eight participants were Indonesians who are actively looking for information about study abroad, and the other ones were Indonesians who are studying abroad in several different countries.

Interviews conducted were semi-structured. The questions were designed to dig behaviors, attitudes, and aptitudes of potential users. For each role in the persona hypothesis, a different set of questions was given. Examples of interview questions can be seen in Table 1 and Table 2 .

TABLE I

EXAMPLES OF QUESTIONS ASKED TO INFORMATION SEEKER PARTICIPANTS

\begin{tabular}{|l|l|}
\hline \multicolumn{1}{|c|}{ Theme } & \multicolumn{1}{c|}{ Question } \\
\hline $\begin{array}{l}\text { The process of } \\
\text { getting a letter of } \\
\text { acceptance (LoA) } \\
\text { and scholarship }\end{array}$ & $\begin{array}{l}\text { When did you start to have a willing to } \\
\text { continue studying abroad? Please tell me } \\
\text { your story of getting your LoA or } \\
\text { scholarship from the start until now! }\end{array}$ \\
\hline $\begin{array}{l}\text { Information } \\
\text { seeking behavior } \\
\text { on the internet }\end{array}$ & $\begin{array}{l}\text { When was the last time you look for } \\
\text { information about studying abroad on the } \\
\text { internet? Please show me how you did it! }\end{array}$ \\
\hline $\begin{array}{l}\text { Asking people } \\
\text { behavior }\end{array}$ & $\begin{array}{l}\text { Whom do you usually ask information about } \\
\text { studying abroad to? How do you ask? Why } \\
\text { do you ask them? }\end{array}$ \\
\hline
\end{tabular}

TABLE III

EXAMPLES OF QUESTIONS ASKED TO INFORMATION PROVIDER PARTICIPANTS

\begin{tabular}{|l|l|}
\hline \multicolumn{1}{|c|}{ Theme } & \multicolumn{1}{c|}{ Question } \\
\hline $\begin{array}{l}\text { Answering } \\
\text { questions } \\
\text { behavior }\end{array}$ & $\begin{array}{l}\text { How do you get approached? Could you sort } \\
\text { them from the most frequent to the least? } \\
\text { Please tell me an example! }\end{array}$ \\
\hline $\begin{array}{l}\text { Accessing } \\
\text { internet behavior }\end{array}$ & $\begin{array}{l}\text { What are your activities when using the } \\
\text { internet? Could you sort them from the most } \\
\text { frequent to the least? }\end{array}$ \\
\hline $\begin{array}{l}\text { Perspective about } \\
\text { people who want } \\
\text { to study abroad }\end{array}$ & $\begin{array}{l}\text { What do you think about Indonesian people } \\
\text { who want to study abroad? }\end{array}$ \\
\hline
\end{tabular}

\section{B. Modeling}

Modeling phase was started by separating interview notes based on pre-defined roles. For each role, behavioral variables were identified. Behavioral variables identified based on the remarks expressed by participants during the interview. From interviews of participants with the role of information seekers, we identified 21 behavioral variables. In addition, from interviews of participants with the role of the information provider, we identified 17 behavioral variables. Example of a behavioral variable identification can be seen in Table 3 .

TABLE IIIII

EXAMPLE OF A BEHAVIORAL VARIABLE IDENTIFICATION BASED ON PARTICIPANT QUOTES

\begin{tabular}{|l|l|}
\hline \multicolumn{1}{|c|}{ Quotes } & Behavioral Variable \\
\hline $\begin{array}{l}\text { "I am anxious about what the } \\
\text { people I ask would think about me; }\end{array}$ & \\
I am afraid they would think that I \\
just want to talk to them when I \\
need them." (Participant A)
\end{tabular}

For each role, interview participants were mapped into its behavioral variables. After all of the participants had been mapped, patterns were then identified. A pattern was formed from two or more participants who were mapped to the same value or close to six or more behavioral variables. The mapping process is done based on an assessment of speech and behavior of participants observed during the interview. Example of participants mapping can be seen in Fig. 2. Th, I, $\mathrm{Ti}, \mathrm{A}, \mathrm{B}, \mathrm{Su}, \mathrm{D}$, and $\mathrm{Sc}$ represent the participants.

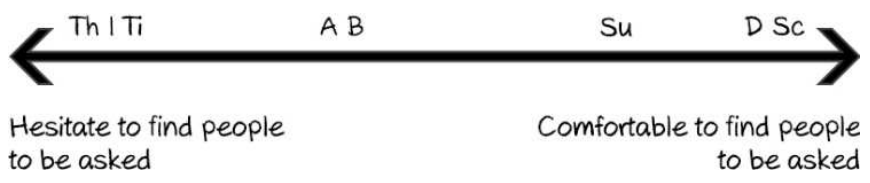

Fig. 2 Example of participants mapping to a behavioral variable

From patterns identified, we took a pattern from each role to be a persona. From the mapping of information seeker participants, we found two patterns. While from the information provider participants, we found four patterns. We chose one pattern from each role based on the behavioral variables mapped by the pattern. The patterns we picked has 
behavioral variables that benefit the most from social Q\&A. Examples of patterns identification can be seen on Fig. 3 .

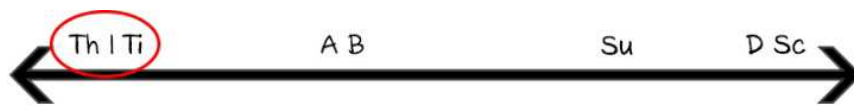

Hesitate to find people to be asked

Comfortable to find people to be asked

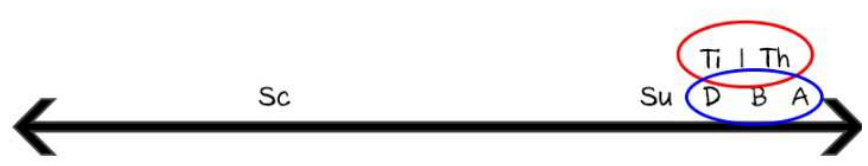

Never google

Google a lot

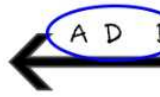

Th 1

Su

$\mathrm{Sc}$

$T$

Never open online forum

Open online forum a lot

Fig. 3 Examples of patterns identification from three behavioral variables

For each persona from each role, we synthesize a combination of characteristics from participants involved, gave a name, and defined goals. Characteristic categories combined included behaviors, environment, pain points, demographics, skills, experience, and aptitudes, as well as attitudes and motivation. We named the information seeker persona Deka and the information provider persona Arshad. An example of characteristics combination can be seen in Table 4.

TABLE IV

EXAMPLE OF CHARACTERISTICS COMBINATION OF A PERSONA

\begin{tabular}{|l|l|}
\hline \multicolumn{1}{|c|}{ Category } & \multicolumn{1}{c|}{ Characteristic } \\
\hline Behavior & $\begin{array}{l}\text { Determine the program he wants to } \\
\text { study, then create a list of and prioritize } \\
\text { universities, and create a list of and } \\
\text { prioritize scholarships. }\end{array}$ \\
\hline Environment & Close friends are college friends. \\
\hline Problem & $\begin{array}{l}\text { Time management between work and } \\
\text { university or scholarship application } \\
\text { preparation. }\end{array}$ \\
\hline Demographics & 24 years old \\
\hline $\begin{array}{l}\text { Skill, experience, } \\
\text { and aptitude }\end{array}$ & $\begin{array}{l}\text { Use the internet every day with laptop } \\
\text { or smartphone }\end{array}$ \\
\hline $\begin{array}{l}\text { Attitude and } \\
\text { emotion }\end{array}$ & $\begin{array}{l}\text { He wants to know important } \\
\text { information he does not know that he } \\
\text { needs to know }\end{array}$ \\
\hline Name & Deka Sutanto \\
\hline Goals & $\begin{array}{l}\text { Find information easily, fast, and } \\
\text { completely because it is structured and } \\
\text { can be browsed well }\end{array}$ \\
\hline
\end{tabular}

Looking into the two personas constructed, social Q\&A can help both of them reach their goals. Nevertheless, goals of information seeker persona will be met more often than information provider personas. Therefore, we selected the information seeker persona as the primary persona and selected the information provider persona as the secondary persona.
For each persona, we constructed a narration from the viewpoint of the third person to explain attitudes, needs, and problems of the persona descriptively. Within the narrative, a photo of a face was also added also added to make the persona more realistic and understandable. Example of a persona narrative can be seen in Fig. 4.

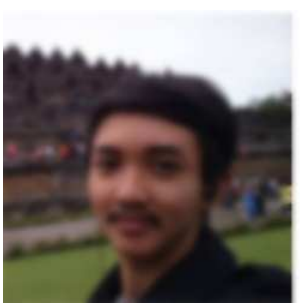

Deka Sutanto is a new employee in a technology startup company in Jakarta. The 24-year-old man just graduated from Universitas Indonesia majoring computer science six months ago. He lives with his family in Jakarta. Deka usually goes hang out with his friends from work and sometimes with his friends from college..

Fig. 4 Example of a persona narrative

\section{Requirement Definition}

In the requirement definition phase, we defined a problem and a vision statement, identified persona expectations, constructed context scenario, and identified design requirement.

The problem statement is a condition that is expected to be changed by the product, whereas the vision statement is an objective to be achieved by the product by meeting user needs. Problem and vision statement can be seen in Fig. 5.

\section{Problem Statement}

Some of Indonesian people still face problems in seeking information about studying abroad because of the information available on the internet today is still limited, messy, and unreliable, while they are reluctant to ask anybody because they are shy and don't whom to ask.

\section{Vision Statement}

Social Q\&A to share information about studying abroad will help users find information and ask more easily, quickly, and complete without information exploration difficulties, unreliability of information, and reluctance to ask problems.

Fig. 5 Problem and vision statements defined

We identified persona expectations from research analysis and persona constructed to understand what personas expect so the product could be developed according to their mental models. Example of a persona expectations identification can be seen in Table 5 .

TABLE V

EXAMPLE OF PERSONA EXPECTATIONS IDENTIFICATION

\begin{tabular}{|c|l|}
\hline \multicolumn{1}{|c|}{ Persona } & \multicolumn{1}{c|}{ Expectations } \\
\hline \multirow{5}{*}{ Deka Sutanto } & $\begin{array}{l}\text { The product has already a lot of questions } \\
\text { and answers, so questions the persona } \\
\text { wants to ask have been asked and } \\
\text { answered }\end{array}$ \\
\cline { 2 - 2 } & $\begin{array}{l}\text { The product has reasonable categorization } \\
\text { with well-performed search system so the } \\
\text { persona could explore quickly and easily }\end{array}$ \\
\cline { 2 - 2 } & $\begin{array}{l}\text { The product gives the expected result } \\
\text { when the persona searches for something }\end{array}$ \\
\hline
\end{tabular}

We constructed context scenarios to describe a common condition experienced by personas when using the product. This condition explains the motivations, needs, and goals of personas. Context scenarios for each persona were 
constructed based on their characteristics in using social Q\&A. Two context scenarios were constructed for the first persona or Deka: when he needs to find information and when he needs to ask a question. The two context scenarios were developed based on the study of [7] which states that majority of social Q\&A users originally did not intend to access the website but the search engines directed them, and users submit a question in social Q\&A because they need answers from people who have a particular experience.

We constructed a scenario for the second persona or Arshad, that is when he needs to answer the questions asked of him. By the persona description, Arshad wants to answer the questions because he understands how hard it is to find information about studying abroad. However, because of other commitments, he could not make such activities a priority. Therefore, in the scenario, Arshad open social Q\&A website through a notification email obtained periodically because email is a communication tool he often uses. An example of a context scenario can be seen in Table 6 .

TABLE VI

EXAMPLE OF A CONTEXT SCENARIO OF A PERSONA

\begin{tabular}{|c|c|}
\hline Persona & Context Scenario \\
\hline \multirow{4}{*}{ Deka Sutanto } & $\begin{array}{l}\text { 1. Deka has decided to continue his studies } \\
\text { at University College London, United } \\
\text { Kingdom (UK), majoring machine } \\
\text { learning. However, he wondered how he } \\
\text { could live there as a Muslim. Within the } \\
\text { working hours, he opened the social Q\&A } \\
\text { site for studying abroad information and } \\
\text { send a question about how to adapt in the } \\
\text { UK as a Muslim. He put "The United } \\
\text { Kingdom" and "Muslim Life" topics on } \\
\text { the question. }\end{array}$ \\
\hline & $\begin{array}{l}\text { 2. After submitting the question, Deka } \\
\text { realizes that the description he wrote in the } \\
\text { question is a bit ambiguous. Then he edits } \\
\text { the question so other users will not be } \\
\text { confused when they read it. }\end{array}$ \\
\hline & $\begin{array}{l}\text { 3. Because he has browsed the site for } \\
\text { several times, Deka knows that there is a } \\
\text { user named Rian who is studying in } \\
\text { London, UK. He thinks that Rian could } \\
\text { help him and request the question to be } \\
\text { answered by him. }\end{array}$ \\
\hline & $\begin{array}{l}\text { 4. Afterward, Deka is curious about } \\
\text { whether anyone has answered his question } \\
\text { and frequently check the question page. }\end{array}$ \\
\hline
\end{tabular}

We analyzed each context scenario, identified persona needs and stored them as design requirements. Example of design requirements identification can be seen in Table 7 .
TABLE VII

EXAMPLE OF DESIGN REQUIREMENTS IDENTIFICATION FROM A CONTEXT SCENARIO

\begin{tabular}{|c|c|}
\hline Context Scenario & Design Requirement \\
\hline \multirow{5}{*}{$\begin{array}{l}\text { Within the working hours, he } \\
\text { opened the social Q\&A site } \\
\text { for studying abroad } \\
\text { information and send a } \\
\text { question about how to adapt } \\
\text { in the UK as a Muslim. He put } \\
\text { "The United Kingdom" and } \\
\text { "Muslim Life" topics on the } \\
\text { question. }\end{array}$} & Create a new account \\
\hline & Log in to account \\
\hline & Submit a question \\
\hline & $\begin{array}{l}\text { Check whether a question has } \\
\text { been asked or not before it is } \\
\text { submitted }\end{array}$ \\
\hline & Give topics to a new question \\
\hline $\begin{array}{l}\text { After submitting the question, } \\
\text { Deka realizes that the } \\
\text { description he wrote in the } \\
\text { question is a bit ambiguous. } \\
\text { Then he edits the question so } \\
\text { other users will not be } \\
\text { confused when they read it. }\end{array}$ & $\begin{array}{l}\text { Edit a question submitted } \\
\text { before }\end{array}$ \\
\hline $\begin{array}{l}\text { Because he has browsed the } \\
\text { site for several times, Deka } \\
\text { knows that there is a user } \\
\text { named Rian who is studying } \\
\text { in London, UK. He thinks that } \\
\text { Rian could help him and } \\
\text { request the question to be } \\
\text { answered by him. }\end{array}$ & $\begin{array}{l}\text { Forward a question to a } \\
\text { particular user }\end{array}$ \\
\hline $\begin{array}{l}\text { Afterward, Deka is curious } \\
\text { about whether anyone has } \\
\text { answered his question and } \\
\text { frequently check the question } \\
\text { page. }\end{array}$ & $\begin{array}{l}\text { Get answers to a question } \\
\text { quickly }\end{array}$ \\
\hline
\end{tabular}

\section{Framework Definition}

Framework definition is a phase where the visual form of the product is developed from the design requirement. In the phase, we defined form factor, posture, and input method. Also, we defined data and functional elements, and defined interaction framework wireframe, key path scenarios, and validation scenarios.

The posture of the social Q\&A product is a sovereign web application. Sovereign posture is the posture for applications that monopolize the user's attention continuously and for long periods of time [3]. Devices targeted for product use are laptops with 14-inch screen size and 1366 × 768 pixels resolution, as they are used often by both personas. Input methods used are those compatible with devices: keyboard, mouse, and touchpad.

From the design requirement identified before, we defined data elements. There were five elements defined: users, questions, answers, comments, and topics. For each data element, we defined the relationship with other data elements, possible conditions, and possible actions applied, and element attributes. Example of data element definition can be seen in Table 8 . 
TABLE VIII

EXAMPLE OF DATA ELEMENTS DEFINITION

\begin{tabular}{|l|l|l|l|l|}
\hline \multicolumn{1}{|c|}{ Data element } & \multicolumn{1}{|c|}{ Relationship } & Condition & \multicolumn{1}{|c|}{ Action } & \multicolumn{1}{c|}{ Attribute } \\
\hline User & $\begin{array}{l}\text { Could create zero } \\
\text { or more } \\
\text { questions, } \\
\text { answers, and } \\
\text { comments }\end{array}$ & Online & Create & Name \\
& $\begin{array}{l}\text { Part of a topic } \\
\text { Have zero or } \\
\text { Question }\end{array}$ & Answered & Create & Short description \\
\hline Created by a user & Unanswered & Edit & Question content \\
& Read & Additional information \\
\hline
\end{tabular}

In addition to data elements, functional elements were also defined by the requirement. In defining functional elements, we referred to common and well-known design principles found in social Q\&A sites, such as showing questions and showing answers. From 33 requirements exist, we defined 79 functional elements. Example of functional elements definition can be seen in Table 9 .

TABLE IX

EXAMPLE OF FUnCTIONAL ELEMENTS DEFINITION

\begin{tabular}{|l|l|}
\hline \multicolumn{1}{|c|}{ Design Requirement } & \multicolumn{1}{c|}{ Functional Element } \\
\hline \multirow{5}{*}{ Create a new account } & Name input field \\
\cline { 2 - 2 } & Email input field \\
\cline { 2 - 2 } & Password input field \\
\cline { 2 - 2 } Log in to account & Registration button \\
\hline & Email input field \\
\cline { 2 - 2 } Submit a question & Password input field \\
\cline { 2 - 2 } & Login button \\
\hline & $\begin{array}{l}\text { Login via Google or Facebook } \\
\text { button }\end{array}$ \\
\hline \multirow{5}{*}{ "Submit A Question" button } \\
\cline { 2 - 2 } & $\begin{array}{l}\text { Modal popup with the content of } \\
\text { input fields and a button to send } \\
\text { the question }\end{array}$ \\
\cline { 2 - 2 } & Question input field \\
\cline { 2 - 2 } & $\begin{array}{l}\text { Question additional information } \\
\text { input field }\end{array}$ \\
\cline { 2 - 2 } & $\begin{array}{l}\text { Question character limitation } \\
\text { text }\end{array}$ \\
\cline { 2 - 2 } & $\begin{array}{l}\text { Question additional information } \\
\text { character text }\end{array}$ \\
\cline { 2 - 2 } Question submit button \\
\hline
\end{tabular}

After all data and functional elements were defined, we group these elements into functional units and define its hierarchy. Functional elements were grouped based on tasks to be accomplished. Example of functional elements grouping can be seen in Table 10 .
TABLE X

EXAMPLE OF FUNCTIONAL ELEMENTS GROUPING BASED ON TASKS

\begin{tabular}{|c|c|c|}
\hline $\begin{array}{c}\text { Functional } \\
\text { Unit }\end{array}$ & Task & Functional Element \\
\hline \multirow{4}{*}{ General } & \multirow{4}{*}{ Search } & Search field for keyword input \\
\hline & & $\begin{array}{l}\text { Question recommendations as } \\
\text { autocomplete result when a } \\
\text { user is typing search keyword }\end{array}$ \\
\hline & & Search button \\
\hline & & $\begin{array}{l}\text { Area for displaying a list of } \\
\text { questions relevant to the } \\
\text { keyword }\end{array}$ \\
\hline \multirow{12}{*}{ Question } & \multirow{3}{*}{$\begin{array}{l}\text { Read a } \\
\text { question }\end{array}$} & Area for displaying a question \\
\hline & & Link to question topic page \\
\hline & & Follow question button \\
\hline & \multirow{4}{*}{$\begin{array}{l}\text { Submit a } \\
\text { question }\end{array}$} & "Submit A Question" button \\
\hline & & $\begin{array}{l}\text { Modal popup with the content } \\
\text { of input fields and a button to } \\
\text { send the question }\end{array}$ \\
\hline & & Question topic input field \\
\hline & & Question submit button \\
\hline & \multirow{5}{*}{$\begin{array}{l}\text { Edit a } \\
\text { question }\end{array}$} & Edit a question button \\
\hline & & Question content input field \\
\hline & & $\begin{array}{l}\text { Question additional } \\
\text { information input field }\end{array}$ \\
\hline & & Question topic edit field \\
\hline & & Save the question button \\
\hline
\end{tabular}

From the data and functional elements grouped and their defined hierarchy, we defined interaction wireframes that explain the interaction and visual form of the product. Wireframe development was done based on the same design principles when identifying functional elements. We used Axure to develop the wireframes. Example of a wireframe can be seen in Fig. 6 . 


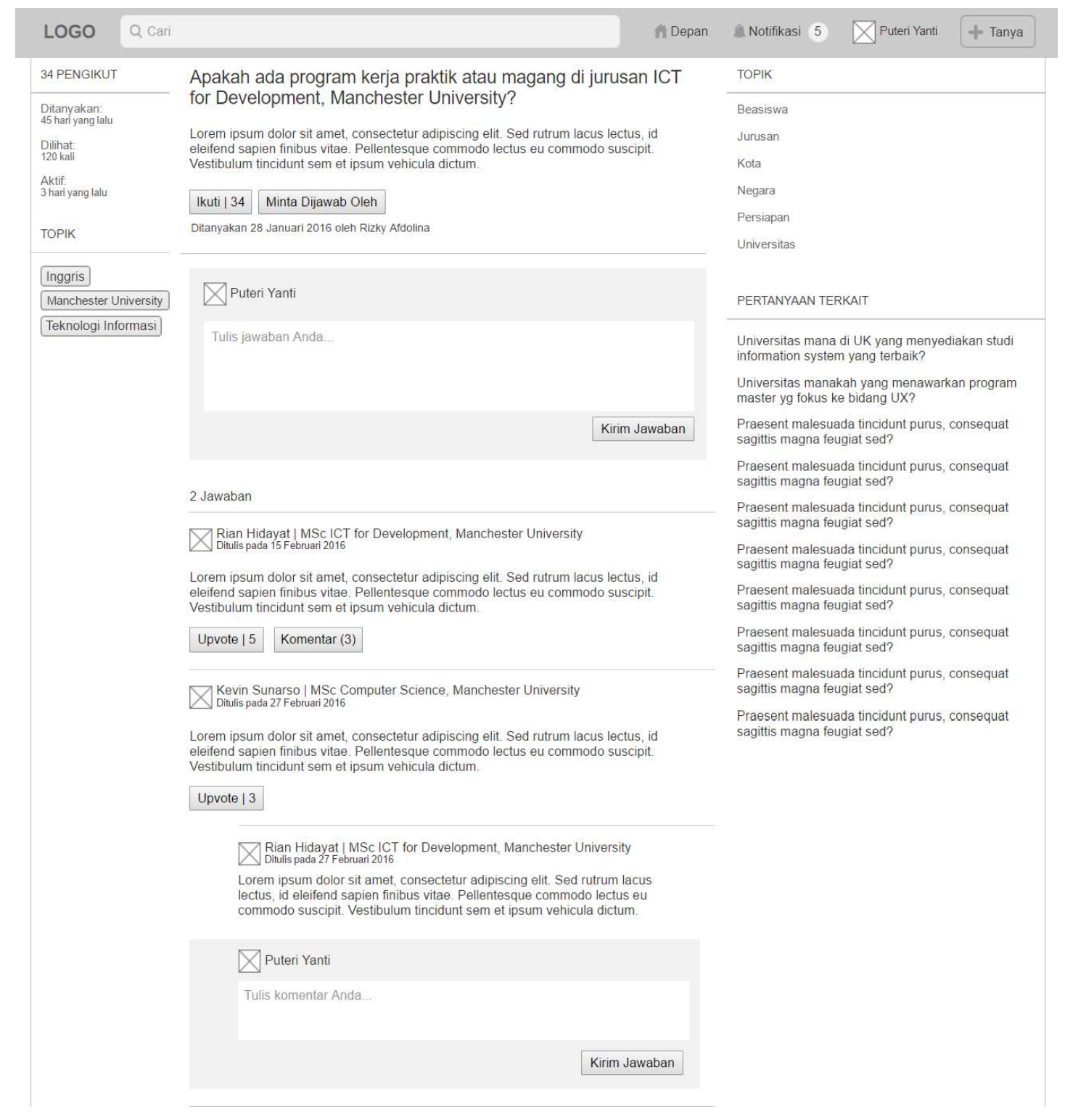

Fig. 6 Question page wireframe

A key path scenario describes the journey of a persona when using the product in details based on tasks that could be done. The scenario describes the interaction between a user with data and functional elements in the product. To facilitate the understanding, we make a storyboard for each scenario with wireframes that depict the process of persona journey in each step. Example of a key path scenario can be seen on Table 11.

TABLE XI

KEY PATH SCENARIO OF DEKA READING A QUESTION

\begin{tabular}{|c|c|c|}
\hline Scenario Step & & Wireframe \\
\hline \multirow{6}{*}{$\begin{array}{l}\text { 1. Deka opens a question page, } \\
\text { read the question content and } \\
\text { additional information. }\end{array}$} & 34 PENGIKUT & $\begin{array}{l}\text { Universitas apa di UK yang memiliki program master jurusan } \\
\text { machine learning paling baik? }\end{array}$ \\
\hline & \multirow{3}{*}{ 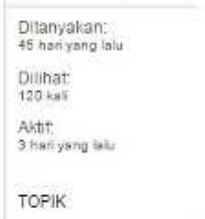 } & $\begin{array}{l}\text { machine learning paling baik? } \\
\text { Saya memilki keinginan untuk melaniutkan kuliah di UK karena waktu kuliah yang cukup } \\
\text { singkat Jurusany yang menjadi terget saya adalah machine learning karena saya } \\
\text { memiliki minat di bidang tersebut dan sejalan dengan } \$ 1 \text { saya yaitu ilmu komputer. }\end{array}$ \\
\hline & & \begin{tabular}{|l|l|} 
Ikuti I 34 & Minta Dijawab Oleh \\
\end{tabular} \\
\hline & & Dtenyak kan 28 Janueri 2018 oleh Ricky Aftdohn \\
\hline & \begin{tabular}{|l|l|l|l|l|l} 
Inggris \\
Manchester University
\end{tabular} & $\triangle$ Deka Sutanto \\
\hline & Teknologi Informasi & Tuls jawaban Anda... \\
\hline
\end{tabular}




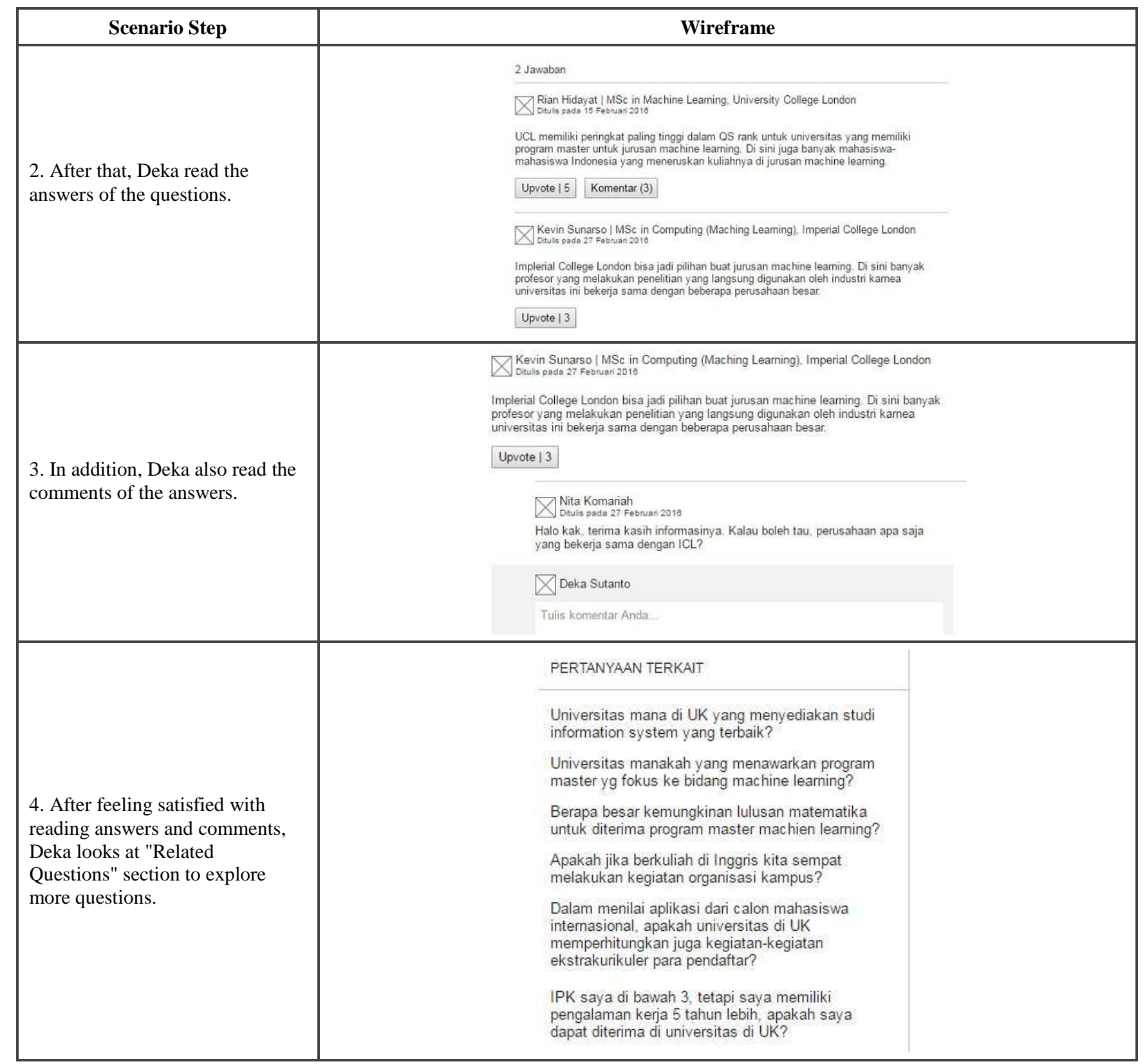

Besides the key path scenarios, we constructed other scenarios that might be done by a persona in the product but not covered in the key path scenarios. These scenarios were not written in stories but defined in the list of possible cases. The scenarios were divided into two types: an alternative scenario and necessary-use scenario (see Table 12).

$$
\text { TABLE XII }
$$

ALTERNATIVE AND NECESSARY-USE SCENARIOS

\begin{tabular}{|l|l|}
\hline \multicolumn{1}{|c|}{ Scenario Case } & \multicolumn{1}{c|}{ Case } \\
\hline \multirow{4}{*}{ Alternative } & $\begin{array}{l}\text { If a persona wants to remove a question } \\
\text { submitted }\end{array}$ \\
\cline { 2 - 2 } & $\begin{array}{l}\text { If a persona wants to edit a comment } \\
\text { submitted }\end{array}$ \\
\cline { 2 - 2 } & If a persona wants to unfollow a topic \\
\hline \multirow{4}{*}{ Necessary-use } & $\begin{array}{l}\text { If a persona wants to change the } \\
\text { password }\end{array}$ \\
\cline { 2 - 2 } & $\begin{array}{l}\text { If a persona wants to mention other } \\
\text { users in a question, answer, or comment }\end{array}$ \\
\hline
\end{tabular}

\section{CONCLUSION}

This study aims to design an interactive system of a social Q\&A product for asking and sharing information about studying abroad using GDD method. We constructed two personas as product users: Deka as an information seeker and primary persona, and Arshad as an information provider and secondary persona. From interview result, we identified 21 behavioral variables for information seeker role and 17 behavioral variables for information provider role. We mapped interview participants to the behavioral variables, and we identified the behavioral patterns. The pattern that formed Deka was chosen because its behavioral variables would benefit the most from the product. Also, a pattern that formed Arshad was chosen because it has the most beneficial behavioral patterns for the product.

As an information seeker who wants to study abroad, Deka has behaviors of hesitating to find people to be asked, having trouble in managing time between work and studying 
abroad preparation, and looking for information on the internet more. While as an information provider, Arshad is frequently asked, even from people he does not know. Arshad also makes an extra effort in providing answers to people who ask him.

We constructed three context scenarios and identified 33 design requirements. The three scenarios were constructed from persona ideal conditions when using the product based on their behavior in seeking and providing information. The scenarios describe how Deka looks through information, Deka submits a question, and Arshad answers a question. Design requirements were identified from the context scenarios. From the design requirements, we identified the data and functionality of the products.

Throughout the study, we developed an interaction design of a social Q\&A product. The design was developed in the form of product wireframes and key path scenarios along with storyboards that describe the interaction in the product. Key path scenarios were constructed based on tasks personas could perform in the product.

The study could be improved by developing visual design framework and conducting usability testing of the design to potential users. Visual design framework could be developed using steps in GDD by people who understand branding and visual design principles. Also, usability testing could be conducted to validate whether the user needs in the product have been met and whether the product is easy to use or not.

\section{REFERENCES}

[1] B. S. E. C. Liu, R. Madhavan, and D. Sudharshan, "DiffuNET: The impact of network structure on the diffusion of innovation," European Journal of Innovation Management, vol. 8, no. 2, pp. 240262, 2005.

[2] G. Wang, K. Gill, M. Mohanlal, H. Zheng, and B. Y. Zhao, "Wisdom in the social crowd," Proceedings of the 22nd international conference on World Wide Web - WWW 13, 2013.

[3] A. Cooper, R. Reimann, D. Cronin, C. Noessel, J. Csizmadi, and D. LeMoine, About face: the essentials of interaction design. Indianapolis, IN: Wiley, 2014.

[4] K. Ortbach, O. Gaß, S. Köffer, S. Schacht, N. Walter, A. Maedche, and B. Niehaves, "Design Principles for a Social Question and Answers Site: Enabling User-to-User Support in Organizations,"
Advancing the Impact of Design Science: Moving from Theory to Practice Lecture Notes in Computer Science, pp. 54-68, 2014.

[5] M. Choetkiertikul, D. Avery, H. K. Dam, T. Tran, and A. Ghose, "Who Will Answer My Question on Stack Overflow?," 2015 24th Australasian Software Engineering Conference, 2015.

[6] S. A. Paul, L. Hong, and E. H.-hsin Chi, "Who is authoritative? Understanding reputation mechanisms in Quora," Proceedings of Collective Intelligence 2012: 1-8, 2012.

[7] V. Kitzie, E. Choi, and C. Shah, "To ask or not to ask, that is the question: Investigating methods and motivations for online Q\&A," Proceedings of HCIR 2012, 2012.

[8] J. Jin, Y. Li, X. Zhong, and L. Zhai, "Why users contribute knowledge to online communities: An empirical study of an online social Q\&A community," Information \& Management, vol. 52, no. 7, pp. 840-849, 2015.

[9] R. Gazan, "Seekers, sloths and social reference: Homework questions submitted to a question-answering community," New Review of Hypermedia and Multimedia, vol. 13, no. 2, pp. 239-248, 2007.

[10] R. Gazan, "Specialists and synthesists in a question answering community," Proceedings of the American Society for Information Science and Technology, vol. 43, no. 1, pp. 1-10, Oct. 2007.

[11] S. Kim, J. S. Oh, and S. Oh, "Best-answer selection criteria in a social Q\&A site from the user-oriented relevance perspective," Proceedings of the American Society for Information Science and Technology, vol. 44, no. 1, pp. 1-15, 2008.

[12] C. Shah, V. Kitzie, E. Choi, "Modalities, Motivations, and Materials - Investigating Traditional and Social Online Q\&A Services". Journal of Information Science, pp. 1-19. 2014.

[13] R. Gazan. "Social Q\&A". Journal of the American Society for Information Science and Technology. vol. 62(12), pp 2301-2312. 2011

[14] C. Shah. "Measuring effectiveness and user satisfaction in Yahoo! Answers". First Monday, vol.16(2), http://firstmonday.org/ojs/index.php/fm/article/view/3092.

[15] C. Shah, JS. Oh and S. Oh. "Exploring characteristics and effects of user participation in online social Q\&A sites". First Monday, vol.13, no.9. http://firstmonday.org/article/view/2182/2028.

[16] S. Pi, C. Chou and H. Liao. "A study of Facebook Groups members' knowledge sharing." Computers in Human Behavior, vol.29, no.5, pp. 1971-1979. 2013

[17] S. Haiying, L. Guoxin, W. Haoyu and V. Nikhil. "SocialQ\&A: An online social network based question and answer system", IEEE Transactions on Big Data, vol.3, no.1. 2017

[18] M. Piero, MA. Luca, and L. Pasquale. "Social Question Answering: Textual, User, and Network Features for Best Answer Prediction". Journal ACM Transactions on Information Systems (TOIS), vol.35(1), no.4, Oct. 2016

[19] A. Williams, "User-centered design, activity-centered design, and goal-directed design," Proceedings of the 27th ACM international conference on Design of communication - SIGDOC 09, 2009 